\title{
MODIFIKASI MEDIA PADA INDUKSI KALUS KOPI ARABIKA (Coffea Arabica L.) BERBUAH KUNING
}

\author{
Ai Yanti Rismayanti ${ }^{1^{*}}$, Hanny Hidayati Nafi'ah ${ }^{1}$
}

\author{
${ }^{1}$ Universitas Garut \\ aiyanti.rismayanti@uniga.ac.id
}

\begin{abstract}
Abstrak
Kopi arabika berbuah kuning sangat potensial untuk dikembangkan petani guna mengatasi rendahnya produktivitas kopi di Kabupaten Garut. Rendahnya produktivitas kopi ini disebabkan antara lain karena sebagian besar tanaman kopi sudah tua, berasal dari varietas lokal/asalan. Varietas kopi lokal yang dikembangkan oleh masyarakat saat ini sebagian besar adalah jenis seedling berasal dari bahan tanaman biji sapuan dengan tingkat produktivitas relatif rendah. Rendahnya ketersediaan bahan tanam kopi bermutu dapat diatasi melalui kultur jaringan. Tujuan penelitian ini untuk mengkaji peran modifikasi media dalam menginduksi kalus kopi arabika Garut berbuah kuning. Penelitian ini menggunakan Rancangan Acak Lengkap (RAL) yang terdiri dari enam perlakuan yang diulang empat kali. Perlakuan terdiri dari $A=$ Kontrol (Tanpa Perlakuan) B = Air Kelapa 20\% + 2,4-D 2,5 mg/l, $\mathrm{C}=$ Air Kelapa 20\%+ 2,4-D 2 mg/l, D= Air Kelapa 20\% + 2,4-D 1,5 mg/l, E= Air Kelapa 20\% + 2,4-D $1 \mathrm{mg} / \mathrm{l}$, dan F = Air Kelapa $20 \%+2,4-\mathrm{D}$ 0,5 mg/l. Bahan tanaman yang digunakan adalah daun kopi arabika lokal garut berbuah kuning. Pengamatan yang dilakukan meliputi waktu inisiasi kalus, persentase pembentukan kalus, dan morfologi kalus. Hasil penelitian menunjukkan bahwa perlakuan $\mathrm{F}$ (Air Kelapa $20 \%+2,4-\mathrm{D} 0,5 \mathrm{mg} / \mathrm{l})$ menghasilkan waktu inisiasi kalus lebih cepat dibandingkan dengan kontrol yaitu 38,5 hari.
\end{abstract}

Kata kunci: arabika, induksi, kalus, air kelapa, 2,4-D.

\section{Pendahuluan}

Berdasarkan data FAO (2017), saat ini Indonesia menjadi salah satu produsen utama kopi keempat setelah Brazil, Vietnam dan Kolombia. Segmentasi pasar kopi specialty memperlihatkan kecenderungan yang kian meningkat, sehingga peluang ini perlu dimanfaatkan sebaik-baiknya bagi pengembangan kopi nasional. Upaya pengembangan tersebut dapat berhasil dengan adanya komitmen terhadap mutu, produksi, harga dan promosi dengan disertai strategi pengembangan yang tepat Direktorat Jenderal Perkebunan (2013). Menurut data Badan Pusat Statistik (2019), total luas areal perkebunan kopi rakyat pada tahun 2017 sebesar 1.192, kemudian meningkat menjadi 1, 210 juta hektar pada tahun 2018 dan meningkat kembali menjadi 1.215 juta hektar pada tahun 2019. Peningkatan luas areal perkebunan ini ternyata tidak sejalan dengan produktivitas dan mutu hasilnya.

Rendahnya produktivitas kopi rakyat disebabkan antara lain karena sebagian besar tanaman kopi sudah tua, berasal dari varietas lokal/asalan. Varietas kopi lokal yang dikembangkan oleh masyarakat saat ini sebagian besar adalah jenis seedling berasal dari bahan tanaman biji sapuan dengan tingkat produktivitas relatif rendah. Berbagai upaya yang dapat dilakukan untuk meningkatkan kuantitas dan kualitas kopi yaitu melalui peremajaan, rehabilitasi, dan intensifikasi tanaman kopi. Salah satu faktor penentu keberhasilan pengembangan kopi tersebut yaitu adanya dukungan ketersediaan bahan tanam unggul dan bermutu.

Salah satu varietas kopi Arabika yang potensial untuk dikembangkan petani kopi di Kabupaten Garut saat ini memiliki karakteristik yang unik, yaitu buahnya tidak berwarna merah ketika masak, melainkan berwarna kuning. Varietas kopi Arabika berbuah kuning banyak ditemukan di wilayah pegunungan Papandayan, Kecamatan Cikajang, Kabupaten Garut yang merupakan sentra perkebunan arabika berbuah kuning di Jawa Barat (Litbang Perkebunan, 2016). Petani setempat menyukai varietas kopi tersebut karena daya hasilnya dinilai tinggi $(>1$ ton/ha) dan ukuran bijinya tergolong besar serta harga jual yang tinggi dibandingkan jenis arabika lainnya. Hasil penelitian sebelumnya menunjukkan bahwa varietas kopi arabika buah kuning menghasilkan biji berukuran besar, sesuai standar SNI 01-2907-2008 Randriani, dkk. (2014). Upaya untuk meningkatkan potensi kopi kuning asal Garut ini telah menjadi perhatian pemerintah antara lain dengan adanya nota kesepahaman antara Pusat Penelitian Kopi dan Kakao Indonesia dengan Dinas Perkebunan Provinsi Jawa Barat pada tanggal 25 Juli 2019 tentang kerjasama pemuliaan tanaman kopi arabika varietas buah kuning hasil eksplorasi di Kabupaten Garut.

Menurut Meynarti, dkk. (2017), kopi Arabika (Coffea arabica L.) merupakan tanaman perkebunan yang dapat diperbanyak secara generatif dengan menggunakan biji dan vegetatif menggunakan setek, okulasi dan sambung pucuk. Perbanyakan menggunakan biji tidak menjamin benih yang 
dihasilkan akan sama dengan induknya, karena tanaman yang menyerbuk sendiri masih ada peluang untuk terjadinya penyerbukan silang.

Perbanyakan vegetatif menghasilkan bibit yang sama dengan induknya, tetapi tidak semua cabang kopi dapat digunakan sebagai sumber bahan tanaman sehingga bibit yang dihasilkan terbatas. Salah satu cara terbaik yang dapat dilakukan untuk mendapatkan sumber bibit berkualitas yaitu melalui teknik kultur jaringan. Teknik kultur jaringan memberikan alternatif dalam perbanyakan kopi. Teknik ini memungkinkan untuk memproduksi bibit yang relatif seragam dalam skala besar, dengan waktu yang lebih singkat, serta bebas hama dan penyakit. Penelitian ini diharapkan menjadi salah satu cara dalam pengembangan dan peningkatan potensi kopi arabika berbuah kuning di Jawa Barat, khususnya di Kabupaten Garut melalui pengadaan bahan tanam unggul dan bermutu.

Keberhasilan kultur jaringan ditentukan oleh media yang digunakan. Media yang sering digunakan dalam teknik kultur jaringan adalah media Murashige and Skoog (MS). Media MS memiliki kandungan garam-garam organik yang dibutuhkan untuk pertumbuhan tanaman serta menyediakan unsur hara makro. Salah satu modifikasi media MS adalah dengan penambahan air kalapa. Menurut Budiono (2004), pemberian air kelapa sampai $20 \%$ mampu meningkatkan pertumbuhan jumlah tunas dan daun bawang merah secara in vitro. Menurut Kristina, dkk., (2012), penggunaan air kelapa pada perbanyakan in vitro tanaman temulawak dengan konsentrasi $15 \%$ memberikan hasil terbaik.

Menurut Kristina, dkk., (2008), kalus dapat dipacu pembentukan dan pertumbuhannya dengan pemakaian ZPT 2,4-D dan sering pula dikombinasikan dengan sitokinin. Auksin 2,4-D merupakan auksin sintetik kuat yang berfungsi memacu pembentukan kalus, pemanjangan/pertumbuhan sel, inisiasi akar dan induksi embriogenesis somatik (Damayanti, dkk., 2005). Penambahan sitokinin BAP berfungsi untuk memacu pembelahan sel, jaringan, organogenesis, menginduksi pembentukan tunas dan proliferasi tunas aksilar (Damayanti dkk., 2005 dan Siti dkk., 2008). Hasil penelitian Defi dkk., (2017), menyatakan bahwa perlakuan 2,4-D 2 ppm menghasilkan kalus yang baik, banyak, inisiasi cepat dan efisien (optimal).

Zat pengatur tumbuh seringkali ditambahkan pada media kultur jaringan. George dan Sherington (1984), menyatakan bahwa pada umumnya media perbanyakan in vitro yang menggunakan zat pengatur tumbuh dari golongan auksin dan sitokinin, yang merupakan zat pengatur tumbuh yang banyak digunakan untuk memacu pembentukan kalus dengan daya aktivitas yang kuat mendorong proses pembelahan sel. Bhojwani (1983), menyatakan bahwa aktivitas utama sitokinin di dalam tanaman adalah mendorong pembelahan sel dan memberikan pengaruh yang efektif terhadap inisiasi tunas. Hal ini didukung hasil penelitian Warner, et.al., (2001), yang menyatakan bahwa sitokinin mempunyai kemampuan mendorong terjadinya pembelahan sel dan difrensiasi jaringan tertentu dalam pembentukan tunas pucuk dan pertumbuhan akar. Terbentuknya akar pada stek dengan cepat akibat auksin yang diberikan bersamaan dengan sitokinin. Setek mampu menyerap nutrisi nutrisi melalui akar yang telah terbentuk tersebut untuk membantu pertumbuhan dan perkembangan tunas menjadi lebih baik.

\section{Bahan dan Metode}

Penelitian ini dilaksanakan pada bulan Agustus November 2020 di Laboratorium Terpadu Faperta Universitas Garut. Bahan yang digunakan adalah eksplan daun kopi arabika berbuah kuning, 2,4-D, air kelapa, media MS, NaOH, Dithane M-45, Calsium hipoklorit, Asam Klorida, agar-agar, gula, Aquades, Alumunium foil, alkohol $70 \%$, bakterisida dan fungisida, dan plastic wraffing. Alat yang digunakan adalah botol kultur, laminar air flow, autoklaf, timbangan analitik, gelas ukur, breaker glass, $\mathrm{pH}$ meter, gelas erlenmeyer, magnetic stirrer, pinset, scalpel, cawan petri, dan bunsen. Penelitian ini menggunakan Rancangan Acak Lengkap (RAL) yang terdiri dari enam perlakuan yang diulang empat kali. Perlakuan terdiri dari :

$\mathrm{A}=$ Kontrol (Tanpa Perlakuan)

B = Air Kelapa 20\% + 2,4-D 2,5 mg/l

$\mathrm{C}=$ Air Kelapa $20 \%+2,4-\mathrm{D} 2 \mathrm{mg} / \mathrm{l}$

$\mathrm{D}=$ Air Kelapa $20 \%+2,4-\mathrm{D} 1,5 \mathrm{mg} / \mathrm{l}$

$\mathrm{E}=$ Air Kelapa $20 \%+2,4-\mathrm{D} 1 \mathrm{mg} / \mathrm{l}$

$\mathrm{F}=$ Air Kelapa 20\% + 2,4-D 0,5 mg/l

Parameter pengamatan meliputi waktu inisiasi kalus, persentase pembentukan kalus dan morfologi kalus meliputi warna dan tekstur. Data pengamatan diolah secara statistik meliputi analisis sidik ragam dan uji lanjut Duncan pada taraf 5\% untuk faktorfaktor yang berpengaruh nyata terhadap parameter pengamatan. Data diinterpretasikan berdasarkan hasil uji statistik tersebut.

\section{Hasil dan Pembahasan}

\section{Waktu inisiasi kalus}

Tahapan pembentukan kalus diawali dengan inisiasi kalus dari eksplan. Dalam penelitian ini inisiasi dilakukan menggunakan eksplan daun. Pengamatan pada keenam media inisiasi pada irisan daun ternyata tidak langsung membentuk kalus, namun didahului dengan pembengkakan jaringan daun seperti yang terlihat pada Gambar 1, meskipun tidak semua eksplan mengalami hal tersebut. Gambar 2 menunjukkan bahwa pemberian 2,4-D, air kelapa memberikan pengaruh yang berbeda nyata terhadap waktu inisiasi kalus. Perlakuan kontrol membutuhkan waktu lebih lama dalam memunculkan tunas yaitu 51.50 hari. Perlakuan pemberian media ditambah air 
kelapa $20 \%+2,4-\mathrm{D} \quad 0,5 \mathrm{mg} / \mathrm{l}$ menghasilkan waktu inisiasi kalus paling cepat yaitu 38,5 hari.

Pembengkakan eksplan merupakan pemanjangan sel yang disebabkan adanya 2,4-D (Gill, et al., 2004). Meskipun beberapa media yang digunakan mengandung 2,4-D, tidak semua media memberikan dampak yang sama pada irisan daun. Pada umumnya daun yang diiris masih berwarna hijau hingga 4 minggu setelah tanam. Lambat laun eksplan berubah warna menjadi kuning kecoklatan dan kemudian berwarna coklat. Pinggiran daun kopi mulai terlihat membengkak setelah empat minggu pada semua media induksi kalus yang digunakan. Pada minggu ke6 pengkalusan di bagian bekas sayatan mulai terbentuk pada media dengan penambahan air kelapa $20 \%+2,4-\mathrm{D} 0,5 \mathrm{mg} / \mathrm{l}$, dan minggu berikutnya pada perlakuan yang lain kecuali pada perlakuan tanpa penambahan ZPT (Kontrol). Hal yang sama dilaporkan oleh Ibrahim dkk., (2012), perlakuan 2,4-D pada kopi arabika mampu menghasilkan kalus.

Pembentukan kalus terlihat semakin berkembang seiring dengan bertambahnya waktu. Dua bulan dalam media induksi, kalus yang terbentuk hanya disekitar bekas sayatan saja. Hal ini juga dijumpai pada penelitian Oktavia dkk., (2003), dimana kalus hanya terbentuk dibekas luka sayatan, namun berbeda dengan hasil penelitian Priyono (1993), yang mendapatkan kalus dan embrio somatik pada permukaan maupun sisi daun. Perbedaan ini diduga karena ada perbedaan ukuran eksplan yang digunakan, perbedaan konsentrasi dan ZPT yang ditambahkan ke media inisiasi kalus, lamanya inisiasi, serta perbedaan respons dari genotipe tanaman yang digunakan sehingga tanggap jaringan berbeda. Pembentukan kalus pada ujung eksplan diawali dengan membesarnya sel-sel epidermis bagian atas kemudian sel-sel tersebut membelah menjadi dua. Pembengkakan pada eksplan menandakan bahwa eksplan sudah merespons media yang diberikan. Media tersebut diserap eksplan sebagai nutrisi untuk pertumbuhan kalus yang selanjutnya akan ditandai dengan tahapan proliferasi (perbanyakan sel) (Wahyuningtiyas dkk, 2014). Ketika tanaman dilukai maka kalus akan terbentuk akibat selnya mengalami kerusakan dan terjadi pemecahan, dan dari sel yang rusak tersebut di hasilkan senyawa-senyawa yang merangsang pembelahan sel di lapisan berikutnya sehingga terbentuk gumpalan sel-sel yang terdiferensiasi (Wahyuningtiyas dkk, 2014).
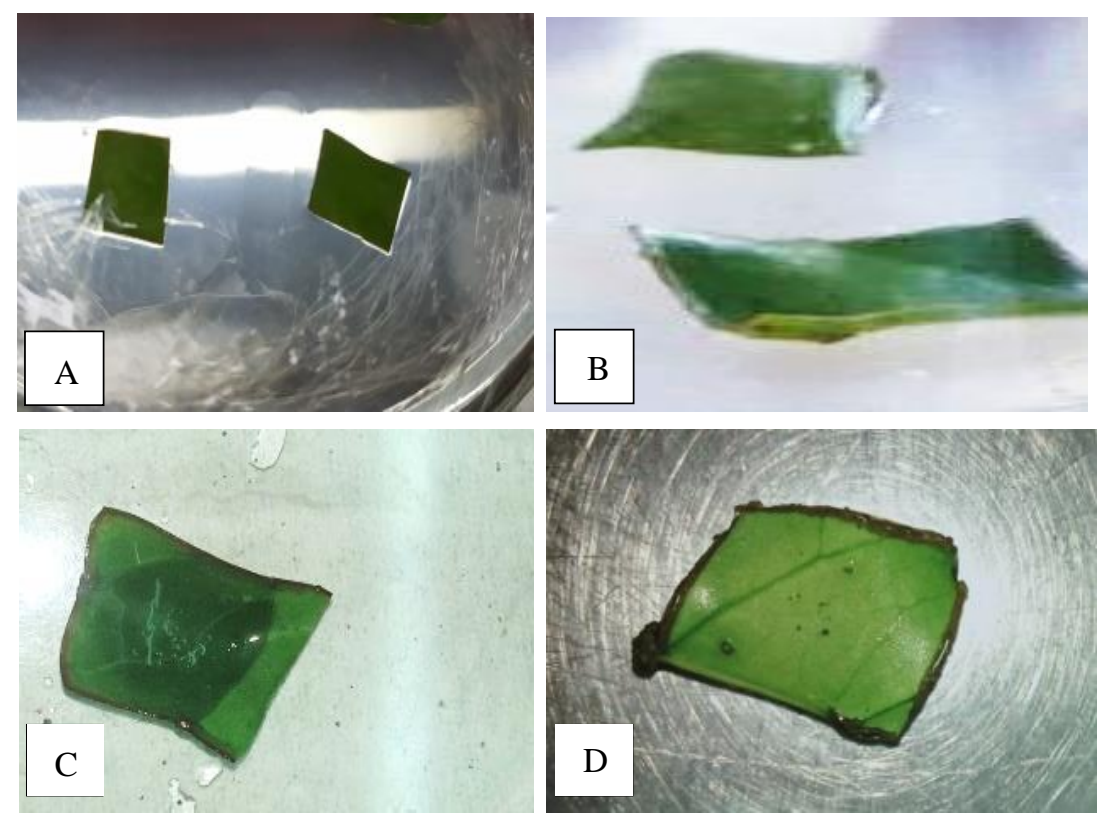

Keterangan: $\quad \mathrm{A}=\mathrm{Awal}$ Penanaman; $\mathrm{B}=$ Pembengkakan dan Pelengkungan; $\mathrm{C}=$ Pengkalusan Bekas Sayatan; $\mathrm{D}=$ Penebalan Pengkalusan.

Gambar 1. Proses Pembengkakan Jaringan Daun 


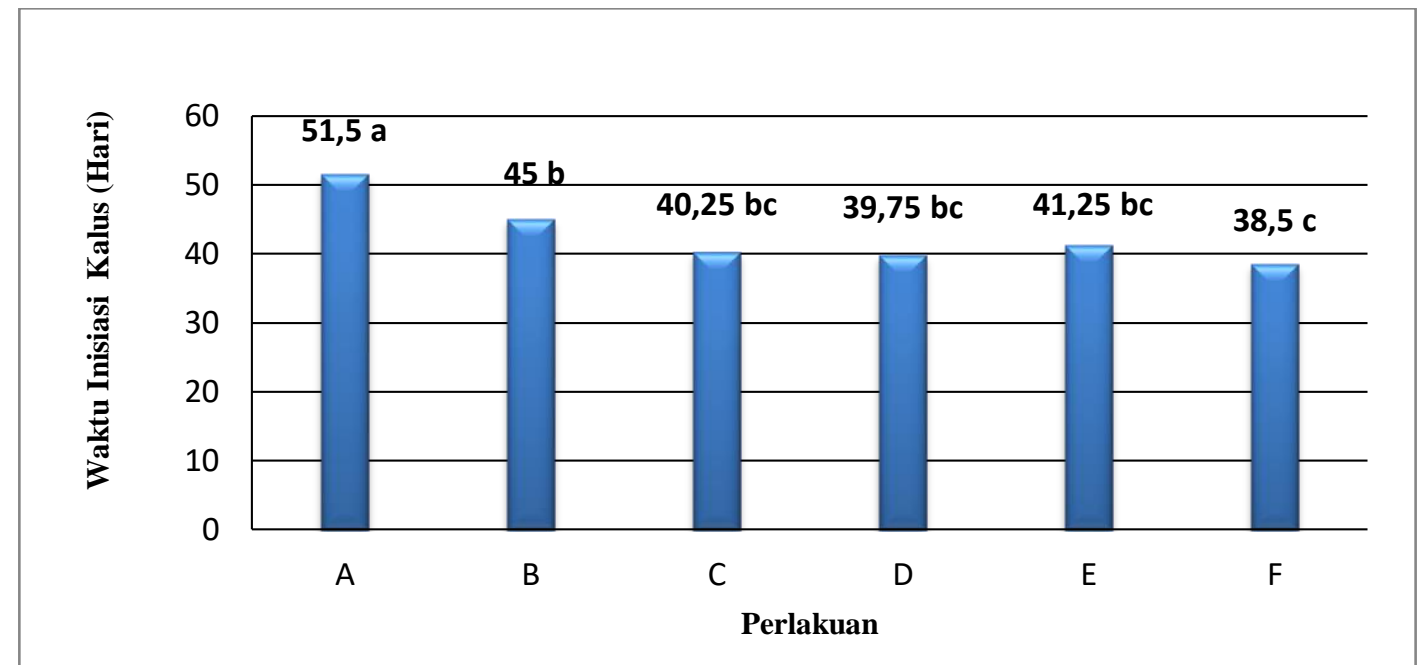

Keterangan : A= Kontrol (Tanpa Perlakuan); B = Air Kelapa 20\% + 2,4-D 2,5 mg/l; C= Air Kelapa 20\%+ 2,4-D 2 mg/l; D= Air Kelapa 20\% + 2,4-D 1,5 mg/l; E= Air Kelapa 20\% + 2,4-D 1 $\mathrm{mg} / \mathrm{l}$, dan F = Air Kelapa $20 \%+2,4-\mathrm{D} 0,5 \mathrm{mg} / \mathrm{l}$. Nilai rata-rata yang ditandai dengan huruf yang sama menunjukkan tidak berbeda nyata berdasarkan uji Duncan pada taraf nyata $5 \%$.

Gambar 2. Waktu Inisiasi Kalus

\section{Persentase Pembentukan Kalus}

Persentase pembentukan kalus menunjukkan tingkat responsif eksplan pada perlakuan yang diuji.
Hasil analisis ragam menunjukkan bahwa konsentrasi auksin $(2,4-\mathrm{D})$ berpengaruh nyata terhadap persentase eksplan berkalus. Persentase eksplan berkalus dari berbagai perlakuan yang diuji disajikan pada Tabel 1 .

Tabel 1. Persentase Pembentukan Kalus

\begin{tabular}{|c|c|}
\hline Perlakuan & Persentase Pembentukan Kalus (\%) \\
\hline A & $65,68 \mathrm{a}$ \\
\hline B & $76,75^{\mathrm{a}}$ \\
\hline $\mathrm{C}$ & $76,77^{a}$ \\
\hline $\mathrm{D}$ & $100,00 b$ \\
\hline $\mathrm{E}$ & $100,00 \mathrm{~b}$ \\
\hline $\mathrm{F}$ & $100,00 b$ \\
\hline \multicolumn{2}{|c|}{$\begin{array}{l}\text { Keterangan : A= Kontrol (Tanpa Perlakuan); B = Air Kelapa } 20 \%+2,4-\mathrm{D} 2,5 \mathrm{mg} / \mathrm{l} ; \mathrm{C}= \\
\text { Air Kelapa } 20 \%+2,4-\mathrm{D} 2 \mathrm{mg} / \mathrm{l} ; \mathrm{D}=\text { Air Kelapa } 20 \%+2,4-\mathrm{D} 1,5 \mathrm{mg} / \mathrm{l} ; \mathrm{E}=\text { Air Kelapa } \\
20 \%+2,4-\mathrm{D} 1 \mathrm{mg} / \mathrm{l} \text {, dan } \mathrm{F}=\text { Air Kelapa } 20 \%+2,4-\mathrm{D} 0,5 \mathrm{mg} / \mathrm{l} \text {. Nilai rata-rata yang } \\
\text { ditandai dengan huruf yang sama menunjukkan tidak berbeda nyata berdasarkan uji } \\
\text { Duncan pada taraf nyata } 5 \% \text {. }\end{array}$} \\
\hline
\end{tabular}

Indikator adanya pertumbuhan dalam kultur in vitro salah satunya adalah pertambahan jumlah sel melalui pembentukan kalus. Menurut Rusdianto (2012), kalus merupakan massa sel yang tidak terorganisir yang terbentuk pada jaringan luka. Sel kalus terbentuk dari sel meristem ataupun sel yang telah mengalami diferensiasi, seperti sel parenchyma pada daun. Sesuai data yang ditampilkan pada Tabel 1, dapat dilihat bahwa persentase pembentukan kalus dari berbagai perlakuan yang dicobakan berkisar antara 65,86-100\%.

Persentase pembentukan kalus tertinggi diperoleh pada jenis auksin 2,4-D pada konsentrasi yang lebih rendah, yaitu mencapai $100 \%$. Hal ini karena konsentrasi tersebut sudah mencukupi konsentrasi optimal untuk pembentangan, diferensiasi, pembelahan dan poliferasi sel sehingga akan mempercepat 
pembentukan kalus. Priyono dan Winarsih (2000), menyatakan bahwa pertumbuhan kalus dipengaruhi oleh nisbah auksin dan sitokinin yang ditambahkan ke dalam media. Hal ini diduga kandungan auksin dan sitokinin endogen lebih berperan dalam pembentukan tunas dan perkembangan eksplan.

Sementara itu, pada jenis auksin dengan konsentrasi yang lebih tinggi, persentase pembentukan kalus tertinggi hanya mencapai $76,77 \%$. Seperti diketahui bahwa ZPT auksin apabila konsentrasinya terlalu tinggi justru akan menghambat pertumbuhan tanaman (Salisbury dan Ross, 1995). Hasil ini menunjukkan bahwa penggunaan air kelapa $20 \%+2,4-$ D $0,5 \mathrm{mg} / \mathrm{l}$ lebih efektif dalam menstimulasi pembentukan kalus pada daun kopi dibanding kontrol.

2,4-D merupakan auksin yang berperan dalam memacu pembelahan dan pembesaran sel sehingga terbentuk massa sel atau kalus. Menurut Rahardja dkk., (2012), penambahan 2,4-D dalam media akan mendorong pembelahan dan pembesaran sel pada eksplan yang selanjutnya akan memacu pembentukan dan pertumbuhan kalus. 2,4-D merupakan jenis auksin sintetik yang efektif mendorong pembelahan sel-sel yang telah mengalami diferensiasi untuk kembali menjadi terdiferensiasi.
Fitriyani (2014), menyatakan bahwa kombinasi antara sitokinin dan auksin juga dapat memberikan respon yang berbeda-beda, tergantung dari spesies, macam organ, umur, dan konsentrasi dari hormon tumbuh itu sendiri, faktor-faktor lingkungan seperti suhu dan cahaya

\section{Morfologi Kalus}

Morfologi kalus yang diamati meliputi tekstur dan warna. Pengamatan dilakukan 1 minggu setelah subkultur, selanjutnya pengamatan dilakukan setiap hari sekali, dan pengamatan ini berlangsung selama 4 minggu. Pengamatan dilakukan untuk melihat respons terbaik kalus kopi.

Tekstur kalus merupakan hal penting untuk diperhatikan dalam proses regenerasi karena dapat menjadi petunjuk awal keberhasilan regenerasi. Pengamatan teksktur kalus ini dilakukan secara visual. Pengamatan tekstur kalus dilakukan pada akhir pengamatan untuk menghindari terjadinya kontaminasi. Tekstur kalus yang dihasilkan pada berbagai kombinasi konsentrasi ZPT dan pada media kultur MS dengan penambahan air kelapa ditampilkan pada Tabel 2.

Tabel 2. Morfologi Kalus

\begin{tabular}{ccc}
\hline Perlakuan & Tekstur & Warna \\
\hline A & Remah & Coklat \\
B & Remah & Coklat \\
C & Remah & Coklat \\
D & Remah & Coklat \\
E & Remah & Coklat \\
F & Remah & Coklat
\end{tabular}

Keterangan : A= Kontrol (Tanpa Perlakuan); B = Air Kelapa 20\% + 2,4-D 2,5 mg/l; C= Air Kelapa 20\%+ 2,4-D 2 mg/l; D= Air Kelapa 20\% + 2,4-D 1,5 mg/l; E= Air Kelapa $20 \%+2,4-\mathrm{D} 1 \mathrm{mg} / \mathrm{l}$, dan F = Air Kelapa $20 \%+2,4-\mathrm{D}$ 0,5 mg/l.

Pembelahan sel-sel pada kalus dipacu oleh hormon endogen dan eksogen auksin dan sitokinin yang ditambahkan pada media kultur. Pertumbuhan dan morfogenesis tanaman secara in vitro dikendalikan oleh keseimbangan dan interaksi dari ZPT yang berada dalam eksplan (endogen) dengan ZPT yang diserap dari media tumbuh (eksogen), Azriati dkk., (2008). Bentuk keseimbangan yang terjadi akan menentukan arah dan bentuk pertumbuhan, sehingga berbagai kombinasi konsentrasi auksin dan sitokinin pada media perlakuan yang seimbang mampu mendorong perkembangan kalus agar tetap hidup.

Perubahan tekstur kalus terjadi karena adanya perubahan kromosom atau gen sehingga meningkatkan keragaman kalus. Hal ini dapat dibuktikan dengan perubahan tekstur kalus sebelum disubkultur yang berstruktur kompak menjadi remah setelah disubkultur.
Wattimena dkk., (1992), menyatakan bahwa pembentukkan kalus atau organ pada kultur in vitro lebih dipengaruhi oleh genotipe, inisiasi kultur, lingkungan tumbuh dan fisiologi jaringan yang digunakan. Perbedaan yang terjadi akan lebih besar jika eksplan tersusun lebih dari satu jenis sel (George dan Sherrington, 1984).

Menurut Street (1973), struktur kalus yang kompak memiliki susunan sel-sel yang rapat, padat dan sulit dipisahkan menjadi klon-klon tunggal. Tekstur kalus yang kompak merupakan efek dari sitokinin dan auksin endogen yang memengaruhi potensial air di dalam sel (Nisak dkk., 2012). Auksin endogen pada kalus akan melonggarkan serat-serat dinding sel, sehingga nutrisi dalam media masuk secara difusi. Hal ini akan terus berlangsung sampai potensial air dan potensial osmotik seimbang dan sel menjadi turgid atau 
membengkaknya sel tumbuhan karena masuknya cairan dari luar ke dalam sel. Sementara kondisi sel menjadi turgid penambahan sitokinin akan memengaruhi pembelahan sel, sehingga pembentukan dinding sel semakin cepat dan kalus menjadi kompak.

Selain tekstur, warna kalus juga merupakan penanda visual untuk menilai pertumbuhan kalus dan keberhasilan suatu regenerasi. Perbedaan warna kalus menunjukkan tingkat perkembangan fase pertumbuhan pada sel. Pada awal pertumbuhan, sebagian besar kalus dari seluruh perlakuan didominasi dengan warna kuning kecoklatan.

Warna kalus mengalami perubahan seiring dengan pertumbuhan umur kalus, yaitu dari berwarna kuning kecoklatan, cokelat dan cokelat gelap. Diduga warna kuning kecoklatan tersebut disebabkan karena klorofil yang terkandung pada kalus. Warna kalus mengindikasikan keberadaan klorofil dalam jaringan, semakin hijau warna kalus semakin banyak pula kandungan klorofilnya (Wahid, 2001). Menurut Lestari dan Mariska (2009), terjadinya perubahan warna kalus dari kecoklatan atau dari kuning menjadi putih kekuningan selanjutnya menjadi kehijauan, merupakan tanda adanya morfogenesis atau tanda bahwa kalus yang diregenerasikan dapat membentuk tunas. Adapun warna cokelat pada kalus disebabkan penuaan. Sel-sel muda yang sehat berwarna kuning, namun akan berubah menjadi cokelat seiring dengan pertumbuhan kalus yang semakin tua (Abdullah dkk., 1998).

Namun, pada beberapa kalus pada awal pertumbuhan sudah nampak gejala pencoklatan. Menurut Lizawati (2012), kalus yang mengalami browning disebabkan oleh bertambahnya umur sel atau jaringan. Perubahan warna tersebut diduga sebagai bentuk respons stres pada kalus, sehingga menstimulasi enzim tertentu untuk membentuk senyawa fenol sebagai bentuk pertahanan diri yang mengakibatkan terjadinya degradasi klorofil pada sel-sel kalus. Kemungkinan lain terjadinya reduksi klorofil pada kalus yaitu disebabkan karena proses senesen pada sel-sel kalus. Ye et.al., (2012), menyatakan bahwa hilangnya kemampuan regenerasi kalus ditandai dengan perubahan morfologi kalus yang semakin longgar, warna kalus yang berubah dari kuning kehijauan menjadi kuning kecoklatan dan menjadi coklat.

Pencoklatan (browning) adalah suatu karakter munculnya warna coklat atau hitam yang sering menghambat pertumbuhan kalus. Peristiwa ini sesunggguhnya merupakan peristiwa alamiah yang sering terjadi. Pencoklatan umumnya merupakan suatu tanda-tanda kemunduran fisiologi kalus. Pencoklatan ini diduga terjadi akibat terlambatnya proses subkultur atau dapat juga disebabkan oleh terlalu lamanya kontak kalus dengan udara luar ketika akan disubkultur.

Browning dipicu oleh reaksi oksidasi senyawa fenol menjadi quinon dan kemudian dipolimerasi menjadi pigmen melaniadin yang berwarna coklat, dimana proses ini dikatalisis oleh enzim fenol oksidase atau polifenol oksidase (Mardiah, 1996). Watson et.al.,
(1998), mengatakan apabila sel-sel kalus dilukai maka sel-sel baru cenderung tumbuh menutupi lukanya dan seiring berjalannya waktu, senyawa fenol akan tertimbun dalam sel-sel ini dan mengeraskan serta menutup lukanya secara efektif. Kegiatan pelukaan kalus pada penelitian ini dilakukan pada saat subkultur sehingga senyawa-senyawa fenol yang tertimbun tersebut menyebabkan kalus cenderung berwarna cokelat.

Tabiyeh et.al., (2006), mengemukakan bahwa pencoklatan dalam kultur jaringan disebabkan karena meningkatnya produksi senyawa fenolat yang diikuti oksidasi oleh aktivitas enzim polifenol oksidase (PPO) dan polimerasinya. Fenilalanin amonia liase (PAL) adalah salah satu enzim dalam fenilpropanoid yang sangat berpengaruh terhadap terjadinya pencoklatan. Salah satu penyebab utama pencoklatan dalam kultur in vitro adalah luka karena pemotongan pada jaringan. Perlukaan terjadi saat pemecahan kalus ke bagian kecil atau teknik subkultur yang kurang hati-hati, seperti penggunaan alat kultur yang masih panas, dan jarak subkultur yang terlalu dekat dengan api bunsen. Luka tersebut memacu stres pada kalus dan menyebabkan peningkatan aktivitas PAL yang diikuti oleh produksi fenilpropanoid dan menyebabkan pencoklatan. Menurut Purnawati (2012), penggunaan jaringan tanaman muda dapat mengurangi kemungkinan browning pada eksplan, karena jaringan tanaman muda memiliki kandungan fenol yang lebih rendah dibandingkan jaringan tanaman yang sudah tua.

\section{Kesimpulan}

Kombinasi air kelapa dan 2,4-D dengan konsentrasi yang berbeda menghasilkan respons pertumbuhan kalus yang berbeda. Kombinasi air kelapa $20 \%$ dan 2,4-D 0,5 $\mathrm{mg} / \mathrm{l}$ merupakan konsentrasi terbaik dalam mempercepat waktu inisiasi kalus dibandingkan dengan kontrol yaitu 38,5 hari dengan persentase eksplan berkalus sebesar $100 \%$. Pada penelitian selanjutnya disarankan untuk menggunakan eksplan tanaman kopi arabika berbuah kuning yang lebih muda untuk menghindari pencoklatan pada kalus.

\section{Ucapan Terima Kasih}

Tim penelitian mengucapkan terima kasih kepada Kemenristekdikti melalui pendanaan hibah Penelitian Dosen Pemula yang didanai Tahun 2020.

\section{Daftar Pustaka}

Abdullah, M. A., Marziah, M., dan Arif, A. B. (1998). Establishment of Cell Suspension Cultures of $M$. elliptica for The Production of Anthraquinones. Plant Cell, Tissue and Organ Culture. (54):173182 
Azriati, E. Asmeliza, N. Yurmita. (2006). Respon Regenerasi Eksplan Kalus Kedelai (Glycine Max (L.) Merrill) Terhadap Pemberian NAA Secara In Vitro. Universitas Negeri Padang. Padang.

Badan Pusat Statistik. (2019). Statistik Kopi Indonesia 2019. Badan Pusat Statistik. Jakarta.

Bhojwani, S. S. M. K. Razdan. (1983). Plant Tissue Culture: Theory and Practic. Development in Crop Science 5. Amsterdam: Elsevier Press.

Budiono, D. P. (2004). Multiplikasi In Vitro Tunas Bawang Merah (Allium ascalonicum L) pada Berbagai Taraf Konsentrasi Air Kelapa. Jurnal Agronomi 8(2):75-80.

Damayanti, F., Murdaningsih H.K., T. Herawati., dan J.S. Darsa. (2005). Tanggap Eksplan Batang Tiga Kultivar Lili terhadap Kombinasi BA dengan Beberapa Taraf 2,4-D pada Medium MS. Zuriat. 16 (1): 60-66.

Defi E., Lilik Setyobudi., dan Tatik Wardiyati. (2017). Pengaruh Tingkat Konsentrasi 2,4-D Dan BAP Pada Media Ms Terhadap Induksi Kalus Embriogenik Temulawak (Curcuma xanthorrhiza Roxb.). Jurnal Produksi Tanaman. 5 (1):140 - 149.

Direktorat Jenderal Perkebunan. (2013). Pedoman Teknis Pengembangan Tanaman Kopi Tahun 2014. Direktorat Jenderal Perkebunan. Jakarta.

Ftriyani W, (2014). Respon Pertumbuhan Kalus Stevia (Stevia rebaudiana B.) Pada Media Ms Dengan Penambahan Zat Pengatur Tumbuh 2,4-D Yang Dikombinasikan Dengan Air Kelapa. Malang.

Food and Agriculture Organization of United Nation. (FAO). (2017). http://faostat.fao.org.

George, F. F. and Sherrington.(1984). Plant Propagation by Tissue Culture. Exegetic Ltd. England.

Gill, N.K., R. Gill, S.S. Gisal. (2004). Factors enhancing somatic embryogenesis and plant regeneration in sugarcane (Saccharum officinarum L.). Indian J. Biochem. 3:119-123.

Ibrahim, M.S.D., Sudarsono, Syafaruddin \& Rubiyo. (2012). Pengaruh Komposisi Media Terhadap Pembentukan Kalus Embriogenesis Somatik Kopi Arabika (Coffea Arabica). Buletin Riset tanaman Rempah dan Aneka tanaman industri. 3 (1), 13-22.

Kristina, N.N., R. Noveriza, S.F. Syahid dan M. Rizal. (2008). Peluang Peningkatan Kadar Kurkumin Pada Tanaman Kunyit Dan Temulawak. Badan Litbang Pertanian. BalittroBogor 9 (2) : 12-17.

Lestari, E.G, Purnamaningsih R., Mariska I., Hutami S. (2009). Induksi Keragaman Somaklonal Dengan Iradiasi Sinar Gamma Dan Seleksi In Vitro Kalus Pisang Rajabulu Menggunakan Asam Fusarat, Serta Regenerasi Dan Aklimatisasi Planlet. Berita Bio. 9(4): 411-417.

Litbang Perkebunan. (2016). Pola Tanam Kopi Di Antara Sayuran: Performa Kopi Arabika Garut Kuning Lebih Baik. litbang.pertanian.go.id. [30 November 2019].
Lizawati. (2012). Induksi Kalus Embriogenik dari Eksplan Tunas Apikal Tanaman Jarak Pagar (Jatropha curcas L.) dengan Penggunaan 2,4 D dan TDZ. Jurnal Fakultas Pertanian, Universitas Jambi, Mendalo Darat, Jambi. 1(2):75-87.

Nisak, K., Nurhidayati, T., dan Purwani, K.I. (2012). Pengaruh Kombinasi Konsentrasi ZPT NAA dan BAP Pada Kultur Jaringan Tembakau Nicotiana tabacum var. Prancak 95. Jurnal Sains dan Seni Pomits. 1(1):1-6.

Mardiah, E. (1996). Penentuan Aktivitas dan Inhibisi Enzim Polifenol Oksidase Dari Apel (Pyrus malus Linn). Jurnal Kimia Andalas. 2:2.

Meynarti S., Sri H., Rubiyo, Agus P., dan Sudarsono. (2017). Efisiensi Media Kultur Dan Aplikasi Temporary Immersion System Pada Embriogenesis Somatik Kopi Arabika. Jurnal Littri 23(1):45-54.

Oktavia, F., Siswanto, Budiani, A., dan Sudarsono (2003). Embriogenesis somatik langsung dan regenerasi planlet kopi arabika (Coffea arabica) dari berbagai eksplan. Menara Perkebunan. 71 (2), 44-55.

Purnawati. (2012). Sterilisasi Tunas Jabon (Anthocepalus cadamba (Roxb.) Miq.) untuk Mendapatkan Eksplan Steril Secara in vitro. IPB Bogor.

Priyono. (1993). Embriogenesis somatik langsung pada kultur in vitro eksplan daun kopi Arabika (Coffea arabica). Jurnal Pertanian Indonesia, 3,16-20.

Priyono dan Winarsih. (2001). Micropropagation of banana (Musa paradisiaca) through cormlet initiation by in vitro culture of apical meristem slices. Jurnal ilmu dasar, vol (2):36-42

Rahardja, B.S, Purwitasari AT, Moch, Alamsjah A. (2012). Pengaruh ZPT Terhadap Pertumbuhan Nannochloropsis oculata. Jurnal of Marine and Coastal Science. 1(2): 71-75.

Randriani, E., Dani, \& Wardiana, E. (2014). Evaluasi Ukuran Biji Beras, Kadar Kafein, dan Mutu Cita Rasa Lima Kultivar Kopi Arabika. Jurnal Tanaman Industri dan Penyegar.

Rusdianto, Indrianto. (2012). Induksi Kalus Embriogenik pada Wortel (Daucus carota) dengan Menggunakan 2,4-D. Jurnal Bionature. 13(2): 136-140.

Salisbury F.B. \& C.W. Ross. (1995). Fisiologi Tumbuhan Jilid 3. Terjemahan. Bandung: Penerbit ITB.

Siti, D.H.Hoesen, Witjaksono., dan L.A Sukamto. (2008). Induksi Kalus dan Organogenesis Kultur In Vitro Dendrobium lineale Rolfe. J. Berita Biologi 9 (3) : 333-342.

Street, H. E. (1973). Plant Tissue and Cell Culture. Los Angeles: University of California Press.

Tabiyeh, D.T., F. Bernard, and H. Shacker. (2006). Investigation Of Glutathione, Salicylic Acid And GA3 Effects On Browning In Pistacia Vera Shoot Tips Culture. ISHS Acta Hort. 726. 
Wahid, R.A. (2001). Efek Radiasi Sinar Gamma Dosis Rendah pada Pertumbuhan Kultur Jaringan Tanaman Ciplukan (Physalis angulata L.). Risalah Pertemuan Ilmiah Penelilian dan Pengembangan Aplikasi Isolop dan Radiasi. 235-240.

Wahyuningtiyas L; R. S Resmisari dan Nashichuddin, (2014). Induksi Kalus Akasia (Acacia mangium) Dengan Penambahan Kombinasi 2,4-D Dan BAP Pada Media MS. Universitas Islam Negeri Maulana Malik Ibrahim Malang.

Wattimena, G. A. (1992). Bioteknologi dalam Pemuliaan Tanaman. Bagian Bioteknologi Tanaman. Departemen Agronomi dan Hortikultura. Fakultas Pertanian, Institut Pertanian Bogor. IPB Press. Bogor. 191.

Ye, X., Chen, Y., Li, J., Yu, X., Feng, J., dan Zheng, X. (2012). Callus Induction and Adventitious Shoot Regeneration in Zizyphus jujuba Mill. Huizao. African Journal of Biotechnology. 